\title{
EVALUASI KINERJA SIMPANG DAN RUAS JALAN SOEKARNO HATTA - R.E. MARTADINATA - TRANS SULAWESI DI PALU
}

\author{
Hj. St. Maryam $\mathbf{H}^{1}$, Lambang Basri Said ${ }^{2}$, Muflihatun Nurfadillah Efendi ${ }^{3}$ \\ ${ }^{1}$ Dosen Jurusan Teknik Sipil Universitas Muslim Indonesia (UMI) \\ Jalan Urip Sumoharjo No.225 Makassar,Telp.454534,_maryammaladia@gmail.com \\ ${ }^{2}$ Dosen Jurusan Teknik Sipil Universitas Muslim Indonesia (UMI) \\ Jalan Urip Sumoharjo No.225 Makassar,Telp.454534, elbasri.umi@yahoo.com \\ ${ }^{3}$ Mahasiswi Magister Tenik Sipil Universitas Muslim Indonesia (UMI). \\ Jalan Urip Sumoharjo No.225 Makassar,Telp.454534, qikygozal02@yahoo.com
}

\begin{abstract}
Abstrak
Kemacetan pada simpang dan ruas Jalan Soekarno Hatta-R.E. Martadinata-Trans Sulawesi di kota Palu merupakan salah satu dampak dari pertumbuhan lalu lintas yang cukup tinggi dan belum berfungsinya sistem lalu lintas yang cukup baik. Dengan memperhatikan kondisi geometri jalan, volume arus lalu lintas, hambatan samping dan lingkungan simpang yang merupakan daerah komersil. Adapun tujuan yang ingin dicapai dari studi ini adalah [1] Menganalisis karakteristik arus lalu lintas pada simpang dan ruas tersebut. [2] Menganalisis kinerja simpang dan ruas pada jalan sekitar wilayah studi. Dan [3] Merumuskan alternatif solusi pada simpang dan ruas jalan tersebut. Penelitian ini bersifat deskriptif yaitu memberikan gambaran terhadap objek yang diteliti, dengan analisis kuantitatif merupakan jenis studi kasus dengan survei dan observasi langsung dilapangan guna mengetahui kinerja simpang dan ruas jalan Soekarno Hatta - R.E. Martadinata - Trans Sulawesi. Hasil penelitian menunjukkan bahwa [1] Karakteristik arus pada simpang dan ruas Jl. R. E. Martadinata - Jl. Soekarno Hatta - Jl. Trans Sulawesi adalah simpang tak bersinyal pada keadaan eksisting dengan adanya parkir disisi jalan mengurangi lebar efektif 6\%. [2] Berdasarkan perhitungan kinerja simpang untuk kondisi simpang tak bersinyal pada keadaan eksisting dengan adanya parkir disisi jalan mengurangi lebar efektif, Hasil perhitungan di dapat derajat kejenuhan (DS) 4,75 detik, untuk Jl. Soekarno Hatta dengan waktu siklus 0,33 detik, dan Jl. Trans Sulawesi dengan waktu siklus 0,35 detik, dan untuk Jl. R. E. Martadinata dengan waktu siklus 0,32 detik. Dan [3] Alternatif pemecahan Masalah Simpang pada ruas Jl. R. E. Martadinata - Jl. Soekarno Hatta - Jl. Trans Sulawesi adalah pemberian rambu lalu lintas di siklus 3 fase dengan durasi 52 detik. Dan Masalah volume lalu lintas dilakukan analisa kanalisasi yang di dapatkan nilai Kapasitas Lajur Kiri (B) adalah 774,6 smp/jam, Derajat Jenuh (DS) adalah 1.66. sedangkan nilai kapsitas Lajur Kanan (C+D) adalah 1389,6 smp/jam, Derajat Jenuh (DS) adalah 1.66.
\end{abstract}

Kata kunci : simpang,kemacetan, parkir sisi jalan.

\section{PENDAHULUAN}

\subsection{Latar Belakang}

Kota Palu sebagai ibu kota provinsi Sulawesi Tengah merupakansalah satu kota yang mengalami perkembangan. Sebagai kota berkembang pertumbuhan penduduk ini diikuti pula dengan pertumbuhan ekonomi. Sejalan dengan pertambahan penduduk dan pertumbuhan ekonomi yang semakin meningkat dari tahun ke tahun, hal tersebut dapat dilihat dari banyaknya pembangunan kawasan permukiman, perkantoran, hotel, pusat perbelanjaan serta pusat rekreasi. Seperti yang kita ketahui bahwa pembangunan kawasan tersebut dapat menimbulkan suatu tarikan pergerakan lalu lintas yaitu sesorang akan melakukan pergerakan untuk memenuhi kebutuhannya, tentu semakin banyaknya orang yang akan melakukan pergerakan harus di 
tunjang pula oleh sarana dan prasarana jalan yang memadai, Apabila kondisi ini tidak ditunjang dengan peningkatan kinerja transportasi, maka akan menimbulkan permasalahan kepadatan lalu lintas. Hal ini terjadi di karenakan semakin meningkatnya jumlah kendaraan bermotor yang dapat menyebabkan kemacetan dan antrian kendaraan yang terjadi pada simpang jalan di Kota Palu, dan dapat mengganggu aktifitas penduduk setempat.

Kemacetan pada simpang dan ruas Jalan Soekarno Hatta-R.E. Martadinata-Trans Sulawesi di kota Palu merupakan salah satu dampak dari pertumbuhan lalu lintas yang cukup tinggi dan belum berfungsinya sistem lalu lintas yang cukup baik.

Dengan memperhatikan kondisi geometri jalan, volume arus lalu lintas, hambatan samping dan lingkungan simpang yang merupakan daerah komersil, maka penulis bermaksud untuk mengangkat Tesis dengan judul : "Evaluasi Kinerja Simpang Dan Ruas Jalan Soekarno Hatta - R.E. Martadinata - Trans Sulawesi di Kota Palu".

\subsection{Rumusan Masalah}

Berdasarkan latar belakang permasalahan, maka berbagai permasalahan yang timbul, sebagai berikut :

1. Bagaimana fenomena karakteristik arus pada simpang dan ruas tersebut.

2. Bagaimana kinerja simpang dan ruas pada jalan sekitar wilayah studi.

3. Bagaimana merumuskan alternatif pemecahan masalah pada simpang dan ruas jalan tersebut.

\subsection{Tujuan Penelitian}

Tujuan penelitian ini sebagai berikut :

1. Menganalisis karakteristik arus lalu lintas pada simpang dan ruas tersebut.

2. Menganalisis kinerja simpang dan ruas pada jalan sekitar wilayah studi.

3. Merumuskan alternatif solusi pada simpang dan ruas jalan tersebut.

\section{METODE PENELITIAN}

\subsection{Pendekatan Penelitian}

Penelitian ini dimulai dari studi literatur terkait dengan permasalahan yang ada diwilayah penelitian,pengamatan secara visual dilapangan, serta pengumpulan data primer dan sekunder, selanjutnya pengolahan data dan analisis sehingga dihasilkan suatu kesimpulan mengenai kinerja simpang dan ruas jalan tersebut.

Penelitian ini bersifat deskriptif yaitu memberikan gambaran terhadap objek yang diteliti, dengan analisis kuantitatif merupakan jenis studi kasus dengan survei dan observasi langsung dilapangan guna mengetahui kinerja simpang dan ruas jalan Soekarno Hatta - R.E. Martadinata - Trans Sulawesi.

\subsection{Lokasi dan Waktu Penelitian}

Penelitian ini dilakukan selama satu (1) minggu. Pengumpulan data ini dilakukan oleh peneliti dan dibantu oleh beberapa orang.

Simpang dan Ruas yang di evaluasi pada penelitian ini adalah simpang tak bersinyal 3 lengan pada Jalan Soekarno Hatta - R.E. Martadinata - Trans Sulawesi.

\section{HASIL DAN PEMBAHASAN}

\subsection{Pengumpulan Data}

Pengumpulan data dilakukan dengan dua cara, yaitu dengan data primer dan data sekunder. Data primer didapat dari pengamatan langsung dilapangan dengan melakukan survey dari tanggal 25 Juni sampai 01 Juli 2018 di simpang tiga Jalan R. E. Martadinata - Jalan Soekarno Hatta - Jalan Trans Sulawesi. Survey yang dilakukan adalah survey geometrik, surve volume lalu lintas, kondisi 
umum dan kondisi lingkungan, sedangkan dat sekunder didapat berdasarkan informasi dari pihak terkait dalam hal ini adalah Dinas Perhubungan kota Palu.

\section{2. Analisa data}

\section{2. 1. Data Volume Lalu Lintas}

Dari hasil Observasi maka dapat di hitugan volume lalu lintas dengan menyesuiakan setiap jenis kendaraan terhadap satuan mobil penumpng (smp) pada setiap periode satu jam. Penyesuaian ini tergantung dari tipe approach atau kaki simpang yang berdasarkan pergerakan kendaraan setiap fase, maka volume approach dapat di hitung dengan rumus :

$$
\text { Protected } \quad: 1,0(L V)+1,3(H V)+0,2(M C)+0,5(U M)
$$

Hasil hitugan volume lalu lintas pada ruas JL. R. E. Martadinata yang ke arah lurus ke arah Jl. Trans Sulawesi sebanyak 2073 smp sedangkan ke arah belok kanan Jl. Soekarno Hatta sebanyak 1262 smp. Volume lalu lintas pada ruas Jl. Soekarno Hatta yang mengarah belok kanan ke arah Jl. Trans Sulawesi sebanyak $1995 \mathrm{smp}$ sedangkan ke arah belok kiri ke arah Jl. R. E. Martadinata sebanyak $1291 \mathrm{smp}$. Volume lalu lintas pada ruas Jl. Trans Sulawesi yang ke arah lurus Jl. R. E. Martadinata sebanyak 2061 smp sedangkan kea rah kiri Jl. Soekarno Hatta sebanyak $2316 \mathrm{smp}$. Rekapitulasi volume lalu lintas pada simpang tiga ruas Jl. R. E. Martadinata - Jl. Soekarno Hatta - J.Soekarno Hatta dapat di lihat pada tabel di bawah ini.

Tabel 1. Total Arus lalu lintas

\begin{tabular}{|c|c|c|c|c|}
\hline Tipe Kendaraan & 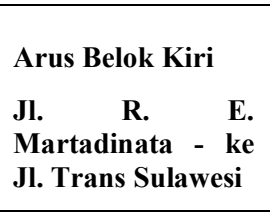 & $\begin{array}{l}\text { Lurus } \\
\text { Jl. R. E. } \\
\text { Martadinata - ke Jl. } \\
\text { Trans Sulawesi }\end{array}$ & 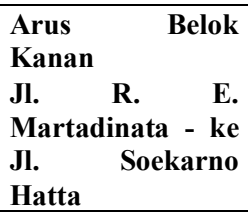 & $\begin{array}{l}\text { Jumlah } \\
\text { Kend/Jam }\end{array}$ \\
\hline LV & 0 & 116 & 83 & 199 \\
\hline $\mathrm{HV}$ & 0 & 950 & 441 & 1391 \\
\hline $\mathrm{MC}$ & 0 & 1007 & 738 & 1745 \\
\hline $\mathrm{UM}$ & 0 & 0 & 0 & $\mathbf{0}$ \\
\hline Total & $\mathbf{0}$ & 2073 & 1262 & \\
\hline
\end{tabular}

\begin{tabular}{|c|c|c|c|c|}
\hline Tipe Kendaraan & $\begin{array}{l}\text { Arus Belok Kiri } \\
\text { Jl. Soekarno Hatta } \\
-\quad \text { ke Jl. R. E. } \\
\text { Martadinata }\end{array}$ & $\begin{array}{l}\text { Lurus } \\
-\end{array}$ & $\begin{array}{lr}\text { Arus } & \text { Belok } \\
\text { Kanan } & \\
\text { Jl. } & \text { Soekarno } \\
\text { Hatta } \quad \text { ke Jl. } \\
\text { Trans Sulawesi } \\
\end{array}$ & $\begin{array}{l}\text { Jumlah } \\
\text { Kend/Jam }\end{array}$ \\
\hline LV & 88 & 0 & 128 & 216 \\
\hline $\mathrm{HV}$ & 436 & 0 & 860 & 1296 \\
\hline $\mathrm{MC}$ & 767 & 0 & 1007 & 1774 \\
\hline UM & 0 & 0 & 0 & $\mathbf{0}$ \\
\hline Total & 1291 & $\mathbf{0}$ & 1995 & \\
\hline
\end{tabular}

Jl.Trans Sulawesi

\begin{tabular}{|l|l|l|l|l|}
\hline & $\begin{array}{l}\text { Arus Belok Kiri } \\
\text { Tipe Kendaraan }\end{array}$ & $\begin{array}{l}\text { Lurus Trans Sulawesi } \\
\text { Jl. Trans Sulawesi } \\
\text { ke Jl. Soekarno } \\
\text { Hatta }\end{array}$ & $\begin{array}{l}\text { Arus Jl. R. E. } \\
\text { Kanan }\end{array}$ & - \\
\hline LV & 143 & 109 & 0 & $\begin{array}{l}\text { Jumlah } \\
\text { Kend/Jam }\end{array}$ \\
\hline
\end{tabular}




\begin{tabular}{|l|l|l|l|l|} 
HV & 1069 & 903 & 0 & $\mathbf{1 9 7 2}$ \\
\hline MC & 1104 & 1049 & 0 & $\mathbf{2 1 5 3}$ \\
\hline UM & 0 & 0 & 0 & $\mathbf{0}$ \\
\hline Total & $\mathbf{2 3 1 6}$ & $\mathbf{2 0 6 1}$ & $\mathbf{0}$ & \\
\hline
\end{tabular}

Volume lalu lintas dengan penyesuaian setiap arah kendaraan terhadap satuan mobil penumpang (smp) pada periode satu jam dapat di lihat sebagai berikut :

Tabel 2. Volume Arus lalu lintas.

\begin{tabular}{|l|l|l|l|}
\hline Pergerakan & $\begin{array}{l}\text { Jl. R. E. } \\
\text { Martadinata }\end{array}$ & Jl. Soekarno Hatta & $\begin{array}{l}\text { Jl. Trans } \\
\text { Sulawesi }\end{array}$ \\
\hline Arus Belok Kiri & 0 & 1291 & 2316 \\
\hline Arus Lurus & 2073 & 0 & 2061 \\
\hline Arus Belok Kanan & 1262 & 1995 & 0 \\
\hline
\end{tabular}

\section{2. 2. Perhitungan kendaraan untuk masing-masing pendekat}

a. Rasio arus belok kiri.

$$
\text { PLT }=\frac{\text { LT }(\mathrm{smp} / \text { jam })}{\text { Total }(\mathrm{smp} / \text { jam })}
$$

b. Rasio arus belok kanan.

$$
\text { PLT }=\frac{\text { LT }(\mathrm{smp} / \text { jam })}{\text { Total }(\mathrm{smp} / \mathrm{jam})}
$$

Volume lalu lintas belokan untuk ruas Jl. R. E. Martadinata untuk belokan kanan sebesar 0,38 Kend/jam, Volume lalu lintas belokan untuk ruas Jl. Soekarno Hatta untuk belokan kiri sebesar 0,39 Kend/jam dan untuk belokan kanan 0,61 ken/jam. Volume lalu intas belokan Jl. Trans Sulawesi untuk belokan kiri sebesar 0,53 kend/jam. Rekapitulasi hasil volume belokan tiap jalan dapat di lihat pada tabel di bawah ini:

Tabel 3. Pendekatan kendaraan

\begin{tabular}{|l|l|l|}
\hline Nama Jalan & $\begin{array}{l}\text { Rasio Belok Kiri } \\
(\text { Kend/Jam) }\end{array}$ & $\begin{array}{l}\text { Rasio Belok Kanan } \\
(\text { Kend/Jam) }\end{array}$ \\
\hline Jl. R. E. Martadinata & 0.00 & 0.38 \\
\hline Jl. Soekarno Hatta & 0.39 & 0.61 \\
\hline Jl. Trans Sulawesi & 0.53 & 0.00 \\
\hline Total & $\mathbf{0 . 9 2}$ & $\mathbf{0 . 9 9}$ \\
\hline
\end{tabular}

\section{3. Penetuan Waktu Sinyal}

\section{3. 1. Lebar Efektif}

Untuk Pendekatan Jalan R. E. Martadinata

Pendekat dengan belok kiri langsung.

Karena Wltor $>2$ meter, Maka lebar efektif

We $=$ Lebar Jalan - Lebar Jalur

$$
\begin{aligned}
& =12-6 \\
& =6 \text { Meter. }
\end{aligned}
$$

Lebar jalan kondisi eksisting adalah 12 meter dan lebar jalur kondisi eksisting adalah 6 meter, Lebar efektif tiap jalan dapat di lihat pada table di bawah ini :

Tabel 4. Lebar Efektif

\begin{tabular}{|c|c|}
\hline Nama Jalan & Lebar Efektif \\
\hline Jl. R. E. Martadinata & $6 \mathrm{~m}$ \\
\hline Jl. Soekarno Hatta & $6 \mathrm{~m}$ \\
\hline Jl. Trans Sulawesi & $6 \mathrm{~m}$ \\
\hline
\end{tabular}




\section{3. 2. Arus Jenuh Dasar}

\section{Untuk Pendekatan Jalan R. E. Martadinata}

$$
\text { So } \quad \begin{aligned}
& =600 \times \mathrm{We} \\
& =600 \times 6 \\
& =3600 \mathrm{smp} / \text { jam hijau }
\end{aligned}
$$

Hasil arus jenuh dasar di hitung dengan mengalikan lebar kondisi eksisting dengan lebar efektif jalan.

\section{3. 3. Faktor-faktor penyesuaian}

a. Faktor koreksi ukuran kota $(\mathrm{Fcs})=0,83$

b. Faktor koreksi hambatan samping (Fsf) $=0,95$

c. Faktor penyesuaian kelandaian $(\mathrm{Fg})=1,00$

d. Faktor koreksi parker $(\mathrm{Fp})=0,85$

e. Faktor koreksi belok kanan $(\mathrm{Frt})=1,06$

f. Faktor koreksi belok kiri (Flt) $=0,99$

Berdasarkan nilai koreksi di atas maka nilai arus jenuh dasar (S) adalah :

$\mathrm{S} \quad=$ So $\mathrm{x}$ Fcs $\mathrm{x}$ Fg $\mathrm{x}$ Fsf $\mathrm{x}$ Fp $\mathrm{x}$ Frt $\mathrm{x}$ Flt

$$
\begin{aligned}
& =3600 \times 0,83 \times 0,95 \times 1,00 \times 0,85 \times 1,00 \times 0,99 \\
& =2532 \mathrm{smp} / \mathrm{jam} \text { hijau }
\end{aligned}
$$

Hasil hitungan arus jenuh didapat untuk ruas Jl. R. E. Martadinata sebesar $2558 \mathrm{smp}$, untuk ruas Jl. Soekarno Hatta sebesar $2532 \mathrm{smp}$ dan untuk ruas Jl. Trans Sulawesi sebesar 2389 smp. Rekapitulasi arus jenuh dasar tiap jalan dapat di lihat pada tabel di bawah ini :

\section{Tabel 5. Nilai Arus Jenuh Dasar (S)}

\begin{tabular}{|l|l|l|l|l|l|l|l|l|}
\hline Nama Jalan & $\begin{array}{l}\text { So (smp/jam } \\
\text { hijau) }\end{array}$ & Fes & Fsf & Fg & Fp & Frt & Flt & $\begin{array}{l}\text { S } \\
\text { (smp/ja } \\
\mathbf{m} \\
\text { hijau) }\end{array}$ \\
\hline Jl. R. E. Martadinata & 3600 & 0.83 & 0.95 & 1.00 & 0.85 & 1.06 & 0 & 2558 \\
\hline Jl. Soekarno Hatta & 3600 & 0.83 & 0.95 & 1.00 & 0.85 & 1.06 & 0.99 & 2532 \\
\hline J1. Trans Sulawesi & 3600 & 0.83 & 0.95 & 1.00 & 0.85 & 0 & 0.99 & 2389 \\
\hline
\end{tabular}

Untuk perhitungan arus lalu lintas (Q)

Untuk Pendekatan Jalan R. E. Martadinata

Arah Selatan $=$ Arus belok kanan + Arus lurus

$$
=1262+2073
$$

$$
=3335
$$

Dari hasil faktor penyesuaian, diperoleh nilai rasio arus (FR) dapat di hitung dengan menjumlahkan nilai FR.

$$
\begin{aligned}
\mathrm{FR} & =\mathrm{Q} / \mathrm{S} \\
& =3335 / 2558 \\
& =1,30
\end{aligned}
$$

Hasil hitungan nilai rasio lalu lintas di dapat untuk ruas Jl. R. E. Martadinata sebesar 1.3 untuk ruas Jl. Soekarno Hatta sebesar 1.32 dan untuk ruas Jl. Trans Sulawesi sebesar 1.4. Rekapitulasi total rasio arus lalu lintas tiap jalan dapat di lihat pada tabel di bawah ini :

Tabel 6. Nilai Rasio lalu lintas

\begin{tabular}{|c|c|}
\hline Nama Jalan & FR \\
\hline Jl. R. E. Martadinata & 1.30 \\
\hline Jl. Soekarno Hatta & 1.32 \\
\hline Jl. Trans Sulawesi & 1.40 \\
\hline IFR & $\mathbf{4 . 0 2}$ \\
\hline
\end{tabular}


Sedangkan untuk rasio fase (PR) dapat di hitung dengan rumus :

Untuk Pendekatan Jalan R. E. Martadinata

$\mathrm{PR}=\mathrm{FR} / \mathrm{IFR}$

$=1,30 / 4,02$

$=0,32$

Hasil hitungan nilai rasio fase di dapat untuk ruas Jl. R. E. Martadinata sebesar 0.32 untuk ruas Jl. Soekarno Hatta sebesar 0.33 dan untuk ruas Jl. Trans Sulawesi sebesar 0.35. Untuk total rasio fa5e jalan lainnya dapat di lihat pada tabel di bawah ini :

Tabel 7. Nilai Rasio Fase

\begin{tabular}{|c|c|}
\hline Nama Jalan & Rasio Fase \\
\hline Jl. R. E. Martadinata & 0.32 \\
\hline Jl. Soekarno Hatta & 0.33 \\
\hline Jl. Trans Sulawesi & 0.35 \\
\hline IFR & $\mathbf{1 . 0 0}$ \\
\hline
\end{tabular}

\section{3. 4. Waktu Siklus (Cua) danWaktu Hijau (g)}

Untuk Pendekatan Jalan R. E. Martadinata

Penentuan waktu siklus dapat di tentukan dengan rumus :

Cua $=(1,5 \times$ LTI +5$)\left(1-\sum\right.$ FRcrit $)$

$=(1,5 \times 8+5)(1)$

$=60$ detik

Keterangan :

Cua = Waktu Siklus sebelum penyesuaian sinyal (detik)

LTI = Total waktu hilang per siklus (detik)

IFR = Rasio arus simpang

Penentuan waktu hijau (g) dapat di tentukan dengan rumus :

g $\quad=($ Cua - LTI $) \times$ PR

gi $\quad=$ Tampilan waktu hijau pada fase i (detik)

Cua = Waktu Siklus sebelum penyesuaian sinyal (detik)

LTI = Total waktu hilang per siklus (detik)

Perhitungan waktu hijau (g)

$\mathrm{g} \quad=(\mathrm{Cua}-\mathrm{LTI}) \times \mathrm{PR}$

$=(60-8) \times 0,32$

$=16,88$ detik

Hasil hitungan waktu siklus hijau lalu lintas di dapat untuk ruas Jl. R. E. Martadinata sebesar 16.88 untuk ruas Jl. Soekarno Hatta sebesar 17.05 dan untuk ruas Jl. Trans Sulawesi sebesar 18.07. Untuk total waktu siklus hijau tiap jalan lihat pada tabel di bawah ini :

Tabel 8. Waktu Siklus

\begin{tabular}{|c|c|c|}
\hline Nama Jalan & Waktu Siklus (Cua) & Rasio Hijau (g) \\
\hline Jl. R. E. Martadinata & 60,00 & 16,88 \\
\hline Jl. Soekarno Hatta & 60,00 & 17,05 \\
\hline Jl. Trans Sulawesi & 60,00 & 18,07 \\
\hline \multicolumn{2}{|c|}{ Total } & $\mathbf{5 2 , 0 0}$ \\
\hline
\end{tabular}

Perhitungan waktu siklus yang di sesuaikan ( C )

$$
\begin{aligned}
\mathrm{C} \quad & =\sum \mathrm{g}+\mathrm{LTI} \\
& =(16,88+17,05+18,07) \\
& =52 \text { detik }
\end{aligned}
$$




$$
\begin{aligned}
& =(\text { Cua }- \text { LTI }) \times \text { PR } \\
& =(52-8) \times 0,32 \\
& =44 \times 0,32 \\
& =14,28 \text { detik }
\end{aligned}
$$

Hasil hitungan waktu siklus hijau penyesuaian waktu lalu lintas di dapat untuk ruas Jl. R. E. Martadinata sebesar 14.28 untuk ruas J1. Soekarno Hatta sebesar 14.43 dan untuk ruas J1. Trans Sulawesi sebesar 15.29. Untuk total waktu siklus hijau penyesuaian waktu tiap jalan lihat pada tabel di bawah ini :

Tabel 9. Waktu Siklus penyesuaian sinyal

\begin{tabular}{|c|c|c|}
\hline Nama Jalan & Waktu Siklus (Cua) & Rasio Hijau (g) \\
\hline Jl. R. E. Martadinata & 52,00 & 14,28 \\
\hline Jl. Soekarno Hatta & 52,00 & 14,43 \\
\hline Jl. Trans Sulawesi & 52,00 & 15,29 \\
\hline \multicolumn{2}{|c|}{ Total } & $\mathbf{4 4 , 0 0}$ \\
\hline
\end{tabular}

\section{4. Kapasitas (C)}

Kemampuan simpang dalam hal kinerjanya terhadap arus lalu lintas persimpangan dapat dilihat dari nilai kapasitas yang didapatkan dari analisa yang kemudian di bandingkan dengan volume arus lalu lintas yang ada. Perhitungan kapasitas untuk persimpangan ini dapat di tentukan dengan rumus :

$$
\mathrm{C} \quad=\mathrm{S}(\mathrm{g} / \mathrm{c})
$$

Keterangan

$$
\begin{aligned}
& \mathrm{C} \quad=\text { Kapasitas }(\mathrm{smp} / \mathrm{jam}) \\
& \mathrm{S} \quad=\text { Arus Jenuh }(\mathrm{smp} / \mathrm{jam}) \\
& \mathrm{c} \quad=\text { Waktu Siklus yang di sesuaiakan (detik) } \\
& \begin{aligned}
\text { Untuk } & \text { Pendekatan Jalan } R . \text { E. Martadinata } \\
\mathrm{C} \quad & =2558(14,28 / 52,00) \\
& =2558 \times 0,27 \\
& =702,45 \mathrm{smp} / \mathrm{jam}
\end{aligned}
\end{aligned}
$$

\section{5. Perilaku lalu lintas}

\section{5. 1. Derajat kejenuhan}

Derajat kejenuhan untuk masing-masing pendekat dapat di hitung dengan rumus :

Untuk Pendekatan Jalan R. E. Martadinata

$$
\begin{aligned}
\mathrm{DS} & =\mathrm{Q} / \mathrm{C} \\
& =3335 / 702,45 \\
& =4,75
\end{aligned}
$$

\section{5. 2. Menghitung jumlah kendaraan antri dan panjang antrian}

a. Panjang antrian

Jumlah antrian pada awal sinyal hijau NQ dihitung sebagai jumlah (smp) yang tersisa dari fase hijau sebelumnya (NQ1) ditambah jumlah (smp) yang datang selama fase merah (NQ2)

Dimana :

NQ1 = Jumlah smp yang tersisa dari fase hijau sebelumnya (smp)

NQ2 = Jumlah smp yang datang selama fase merah )smp)

DS = Derajat kejenuhan

c $\quad=$ Waktu siklus (detik)

$\mathrm{Q}=$ Arus lalu lintas pada pendekatan tersebut (smp/jam)

NQ1 $=0,25 \times C \times\left[(D S-1)+\sqrt{(D S-1)^{2}+\frac{8 x(D S-0,5)}{C}}\right.$

Untuk Pendekatan Jalan R. E. Martadinata

$$
\begin{aligned}
\mathrm{NQ} 1 & =0,25 \times 702,45 \times\left[(4,75-1)+\sqrt{(4,75-1)^{2}+\frac{8 \times(4,75-0,5)}{702,45}}\right. \\
& =1317,38 \mathrm{smp} \\
\mathrm{NQ} 2 & =C \times \frac{1-G R}{1-G R \times D S} \times \frac{Q}{3600} \\
& =702,45 \times \frac{1-0,27}{1-0,27 \times 4,75} \times \frac{3335}{3600}
\end{aligned}
$$


$=137,06 \mathrm{smp}$

Untuk jumlah antrian total diperoleh :

$$
\begin{aligned}
\mathrm{NQ} & =\mathrm{NQ} 1+\mathrm{NQ} 2 \\
& =1317,38+137,06 \\
& =1454,45 \mathrm{smp}
\end{aligned}
$$

b. Kendaraan henti

$$
\begin{aligned}
\mathrm{NS} & =0,9 \times \frac{N Q}{Q x C} \times 3600 \\
& =0,9 \times \frac{1454,45}{3335 \times 702,45} \times 3600 \\
& =2,01 \mathrm{smp} / \mathrm{jam}
\end{aligned}
$$

Untuk menentukan kendaraan henti :

$$
\begin{aligned}
\mathrm{Nsv} & =\mathrm{Q} \times \mathrm{NS}(\mathrm{smp} / \mathrm{jam}) \\
& =3335 \times 2,01 \\
& =6708,57 \mathrm{smp} / \mathrm{jam}
\end{aligned}
$$

Perhitungan untuk tundaan lalu lintas dan tundaan geometrik masing-masing ruas jalan pada persimpangan yang dapat kita lihat dengan contoh perhitungan salah satu ruas jalan yang ada :

\section{Untuk Pendekatan Jalan R. E. Martadinata}

a. Tundaan

Rumus untuk menghitung tundaan :

DT $=C x A+\frac{N Q 1 \times 3600}{C}$

Dimana :

DT = Tundaan lalu lintas rata-rata (detik/smp)

c $\quad=$ Waktu Siklus yang di sesuaikan (detik)

A $\quad=0,5 \times(1-\text { GR })^{2} /(1-$ GR $\times$ DS $)$

$\mathrm{C}=$ Kapasitas (smp/jam)

NQ1 = Jumlah smp tersisa dari fase hijau sebelumnya (smp/jam)

DT $=C x \frac{0,5 \times(1-G R)^{2}}{(1-G R \times D S)}+\frac{N Q 1 \times 3600}{C}$

$=702,45 x \frac{0,5 \times(1-0,27)^{2}}{(1-0,27 \times 4,75)}+\frac{1317,38 \times 3600}{702,45}$

$=6805,18 \mathrm{smp} / \mathrm{jam}$

b. Tundaan Geometrik

Rumus untuk menghitung tundaan Geometrik :

$\mathrm{DGj}=(1-\mathrm{Psv}) \times \mathrm{Pt} \times 6(\operatorname{Psv} \mathrm{x} 4)$

Dimana :

DGj = Tundaan geometrik rata-rata untuk pendekat $\mathrm{j}$ (detik/smp)

Psv $=$ Rasio kendaraan terhenti pada pendekat min (NS1)

Pt $=$ Rasio kendaraan berbelok pada pendekat

DG $=(1-6,5) \times 1 \times 6+(6,5 \times 4)$

$=858 \mathrm{detik} / \mathrm{smp}$

$\mathrm{D} \quad=\mathrm{DT}+\mathrm{DG}$

$=6805,18+858$

$=7663 \mathrm{smp} / \mathrm{jam}$

\section{6. Rekapitulasi Hasil Analisa Kinerja Simpang Bersinyal}

Dari hasil analisa simpang di dapatkan nilai derajat kejenuhan untuk Jl. R. E. Martadinata dengan waktu siklus 4,75 detik, untuk Jl. Soekarno Hatta dengan waktu siklus 0,37 detik, dan Jl. Trans Sulawesi dengan waktu siklus 0,41 detik. Hal tersebut dapat di lihat pada tabel di bawah ini

\section{Tabel 10. Rekapitulasi hasil analisa kinerja simpang.}

\begin{tabular}{|l|c|c|c|c|c|c|c|c|c|c|c|}
\hline Nama Jalan & Q & C & DS & $\begin{array}{c}\text { NQ1 } \\
\text { (smp) }\end{array}$ & $\begin{array}{c}\text { NQ2 } \\
\text { (smp) }\end{array}$ & NQ & $\begin{array}{c}\text { NS } \\
\text { (smpljam) }\end{array}$ & $\begin{array}{c}\text { Nsv } \\
\text { (smpljam) }\end{array}$ & DT & DG & D \\
\hline Jl. R. E. Martadinata & 3335 & 702,45 & 4,75 & 1317,38 & 137,06 & 1454,45 & 2,01 & 6708,57 & 6805,18 & 858 & 7663 \\
\hline Jl. Soekarno Hattla & 3335 & 702,45 & 4,75 & 1317,41 & 137,06 & 1454,47 & 2,01 & 6708,68 & 6804,72 & 594 & 7399 \\
\hline Jl. Trans Sulawesi & 3335 & 702,45 & 4,75 & 1317,38 & 137,06 & 1454,45 & 2,01 & 6708,57 & 6803,74 & 858 & 7662 \\
\hline
\end{tabular}




\section{7. Rekapitulasi Hasil Durasi Tiap Fase.}

Dari hasil analisa simpang di dapatkan nilai durasi waktu untuk Jl. R. E. Martadinata fase merah 34,72 detik fase hijau 14.28 detik fase kuning 3 detik. Untuk ruas Jl. Soekarno Hatta fase merah 34,57 detik fase hijau 14.43 detik fase kuning 3 detik. Untuk ruas Jl. Trans Sulawesi fase merah 33,71 detik fase hijau 15.29 detik fase kuning 3 detik . Rekapitulasi nilai durasi tiap jalan lihat pada tabel di bawah ini :

Tabel 11. Rekapitulasi hasil Durasi Tiap Fase.

\begin{tabular}{|l|l|l|l|l|}
\hline Nama Jalan & $\begin{array}{l}\text { Waktu Siklus } \\
\text { (Cua) }\end{array}$ & $\begin{array}{l}\text { Rasio } \\
\text { Hijau (g) }\end{array}$ & $\begin{array}{l}\text { Rasio } \\
\text { Kuning }\end{array}$ & Rasio Merah (DGj) \\
\hline Jl. R. E. Martadinata & 52.00 & 14,28 & 3.00 & 34,72 \\
\hline Jl. Soekarno Hatta & 52.00 & 14,43 & 3.00 & 34,57 \\
\hline Jl. Trans Sulawesi & 52.00 & 15,29 & 3.00 & 33,71 \\
\hline
\end{tabular}

\section{8. Rekapitulasi Hasil Kanalisasi}

Dari hasil analisa kanalisasi di dapatkan nilai

Dimana :

$0,6=$ Lebar jalur jalan.

$\mathrm{Q} \quad=$ Jumlah Volume dari semua jenis kendaraan.

1. Kapasitas Lajur Kanalisasi Arah Jalan Soekarno Hatta ke Jalan R.E. Martadinata

$$
\begin{aligned}
& \mathrm{A} \quad=0,6 \times \mathrm{Q} \\
& =0,3 \times 1291 \\
& =774,6 \mathrm{smp} / \mathrm{jam}, \\
& \begin{aligned}
\text { Derajat } & \text { Jenuh }(\mathrm{DS}) \\
\mathrm{DS} \quad & \mathrm{Q} / \mathrm{B} . \\
& =1291 / 774,6 \\
& =1.66 .
\end{aligned}
\end{aligned}
$$

2. Kapasitas Lajur Kanalisasi Arah Jalan Trans Sulawesi ke Jalan Soekarno Hatta

$$
\begin{aligned}
\mathrm{B} & =0,6 \times \mathrm{Q} \\
& =0,3 \times 2316 \\
& =1389,6 \mathrm{smp} / \mathrm{jam},
\end{aligned}
$$

Derajat Jenuh (DS).

$$
\begin{aligned}
\mathrm{DS} & =\mathrm{Q} / \mathrm{CD} . \\
& =2316 / 1389,6 \\
& =1.66 .
\end{aligned}
$$

Dari hasil Kanalisasi di dapat untuk Kapasitas Lajur Kanalisasi Arah Jalan Soekarno Hatta ke Jalan R.E. Martadinata sebesar 774,6 smp/jam, Derajat Jenuh (DS) sebesar 1.66. untuk Kapasitas Lajur Kanalisasi Arah Jalan Trans Sulawesi ke Jalan Soekarno Hatta sebesar $1389.6 \mathrm{smp} / \mathrm{jam}$. Derajat Jenuh (DS) sebesar 1.66. Rekapitulasi nilai kanalisasi jalan lihat pada tabel di bawah ini :

Tabel 12. Rekapitulasi Volume Kanalisasi Lalu Lintas

\begin{tabular}{|c|c|c|c|c|c|c|}
\hline \multirow{2}{*}{ Pukul } & \multicolumn{3}{|c|}{$\begin{array}{c}\text { Arah Jl. Soekarno Hatta ke Jl. R. E. } \\
\text { Martadinata }\end{array}$} & \multicolumn{2}{c|}{ Arah J. Soekarno Hatta ke Jl. Trans Sulawesi } \\
\cline { 2 - 7 } & $\begin{array}{c}\text { Kendaraan } \\
\text { berat / Heavy } \\
\text { Vehicle (HV) }\end{array}$ & $\begin{array}{c}\text { Kendaraan } \\
\text { ringan / Light } \\
\text { Vehicle (LV) }\end{array}$ & $\begin{array}{c}\text { Sepeda } \\
\text { motor / } \\
\text { Motor Cycle } \\
\text { (MC) }\end{array}$ & $\begin{array}{c}\text { Kendaraan } \\
\text { berat / Heavy } \\
\text { Vehicle (HV) }\end{array}$ & $\begin{array}{c}\text { Kendaraan } \\
\text { ringan / Light } \\
\text { Vehicle (LV) }\end{array}$ & $\begin{array}{c}\text { Sepeda motor / } \\
\text { Motor Cycle } \\
\text { (MC) }\end{array}$ \\
\hline $07.00-09.00$ & 30 & 151 & 234 & 38 & 355 & 358 \\
\hline $12.00-14.00$ & 31 & 144 & 252 & 31 & 347 & 356 \\
\hline $16.00-18.00$ & 27 & 141 & 281 & 74 & 367 & 390 \\
\hline \multirow{2}{*}{ Jumlah (Q) } & 88 & 436 & 767 & 143 & 1069 & 1104 \\
\cline { 2 - 7 } & \multicolumn{7}{|c|}{1291} & & 2316 & \\
\hline
\end{tabular}




\section{KESIMPULAN}

Hasil penelitian menunjukkan bahwa [1] Karakteristik arus pada simpang dan ruas Jl. R. E. Martadinata - Jl. Soekarno Hatta - Jl. Trans Sulawesi adalah simpang tak bersinyal pada keadaan eksisting dengan adanya parkir disisi jalan mengurangi lebar efektif 6\%. [2] Berdasarkan perhitungan kinerja simpang untuk kondisi simpang tak bersinyal pada keadaan eksisting dengan adanya parkir disisi jalan mengurangi lebar efektif, Hasil perhitungan di dapat derajat kejenuhan (DS) 4,75 detik, untuk Jl. Soekarno Hatta dengan waktu siklus 0,33 detik, dan Jl. Trans Sulawesi dengan waktu siklus 0,35 detik, dan untuk J1. R. E. Martadinata dengan waktu siklus 0,32 detik. Dan [3] Alternatif pemecahan Masalah Simpang pada ruas Jl. R. E. Martadinata - Jl. Soekarno Hatta - Jl. Trans Sulawesi adalah pemberian rambu lalu lintas di siklus 3 fase dengan durasi 52 detik. Dan Masalah volume lalu lintas dilakukan analisa kanalisasi yang di dapatkan nilai Kapasitas Lajur Kiri (B) adalah 774,6 smp/jam, Derajat Jenuh (DS) adalah 1.66. sedangkan nilai kapsitas Lajur Kanan (C+D) adalah 1389,6 smp/jam, Derajat Jenuh (DS) adalah 1.66.

\section{SARAN}

Berdasarkan hasil yang diperoleh dari penelitian yang telah dilakukan, terdapat beberapa saran yang diberikan, sebagai berikut:

1. Perlu di adakan pengaturan survey ulang untuk penentuan/pengaturan ulang waktu lalu lintas pada traffic light persimpangan.

2. Pada simpang tiga lengan di ruas Jl. R. E. Martadinatga - Jl. Soekarno Hatta - Jl. Trans Sulawesi, perlu di rencanakan gedung/area parkir karena di lokasi tersebut adalah lokasi pertokoan.

3. Diperlukan penelitian lebih lanjut mengenai kanalisasi pada simpang tiga lengan di ruas di Jl. R. E. Martadinatga - Jl. Soekarno Hatta - Jl. Trans Sulawesi.

\section{DAFTAR PUSTAKA}

Badan Pusat Statistik, 2015, Jumlah Penduduk Menurut Kecamatan, Palu.

Departemen Pekerjaan Umum Direktorat Jendral Bina Marga "Manual Fivi Zulfianilsih Dan Ulfa Jusi, 2016. Analisa Kinerja Ruas Jalan Berdasarkan Derajat Kejenuhan Jalan, Tugas Akhir, Program Studi Teknik Sipil, Sekolah Tinggi Teknologi Pekanbaru.

Kapasitas Jalan Indonesia (MKJI) 1997 "DLLAJR 1 "Studi Transportation Engineering I", 1987, Khisty .C. Jotin dan Lall B. Kent,"Dasar-dasar Rekayasa Transportasi Jilid-1”, Erlangga, 2005.

Muchson Effendi, 2014. Evaluasi Kinerja Simpang Tak Bersinyal Gondang Kota Surakarta, Tugas Akhir, Program Studi DIII Teknik Sipil, Fakultas Teknik, Universitas Sebelas Maret Surakarta.

Ridwan Ali Rhois, 2014, Kecepatan Dalam Ilmu Transportasi, https://ridwanalirhois.wordpress.com/2014/10/25/kecepatan-dalam-ilmutransportasi/.

2014. Rekayasa Lalu Lintas Dan Persimpangan Jalan, https://www.academia.edu/9582478/REKAYASA_LALU_LINTAS_DAN_PERSI MPANGAN JALAN.

Wells G. R.,"Rekayasa Lalu Lintas”, Penerbit BHRATARA 1993 